\title{
TREATMENT OF WASTEWATER FROM SWINE AND POULTRY SLAUGHTERHOUSES
}

\author{
MIRELA SUCEVEANU ${ }^{1}$, IULIAN SUCEVEANU², LUMINIŢA GROSU ${ }^{1}$, \\ IRINA-CLAUDIA ALEXA ${ }^{1 *}$ \\ 1 "Vasile Alecsandri" University of Bacau, Engineering Faculty, Department of Chemical \\ and Food Engineering Calea Marasesti 157, Bacau, 600115, Romania \\ ${ }^{2}$ S.C. Agricola S.A., 94 Calea Moldovei, 600115, Romania
}

\begin{abstract}
The meat processing industry produces large volumes of slaughterhouse wastewater (SWW). For this reason, water and wastewater treatment has become crucial for the continuing development of the society. The present study reveals the water pollution degree from poultry and the swine slaughterhouses from Bacau (Romania). The possibility of reducing the quantity of pollutants by the active sludge treatment method is also presented. The efficiency of this treatment processes was evaluated through the following parameters: biochemical oxygen demand $\left(\mathrm{BOD}_{5}\right)$, chemical oxygen demand (COD), total suspended solids (TSS), turbidity, both before and after the active sludge treatment.
\end{abstract}

Keywords: wastewater, pollution, slaughterhouse, pig, poultry

\section{INTRODUCTION}

Wastewater from the meat processing industry is formed at slaughterhouses, meat processing plants and cattle and poultry farms, and is an important source of surface water pollution. It represents a serious problem due to their high levels of organic matter which demands effective and high cost treatments.

According to statistical data from literature [1-3], the meat processing industry is one of the major consumers of freshwater among food and beverage processing facilities, which makes slaughterhouses a significant producer of wastewater effluents. Widely, a slaughterhouse plant that may consume between 2.5 and $40 \mathrm{~m}^{3}$ of water per metric tons of meat produced [1]. This wastewater is considered with potentially highly detrimental effects for environment due to its complex composition of fats, proteins, and fibers from the slaughtering process. SWW is initially stained due to blood and stomach contents, bleeding due to blood presenting with difficulty in removal due to hemoglobin that is not completely removed by coagulation and which is resistant to biological treatment and is decomposed over time [4-6].

The direct discharge of the SWW effluents to a water body is impractical due to their high organic charge. According to the European Union legislation, slaughterhouses commonly discharge the SWW into the municipal sewer system after a preliminary onsite treatment. So, the treatment of wastewater from the meat processing industry has been one of the greatest concerns of the agro-industrial sector $[7,8]$.

An option to allow pre-treatment of wastewater in good conditions may be grouping the channels according to the water specificity as follows: waters containing predominantly suspended matter, waters containing fat and waters containing blood [4].

\footnotetext{
* Corresponding author, email: irinaalexa@ub.ro

(C) 2018 Alma Mater Publishing House
} 
Waste water resulting from the slaughter of pigs has a high fat content and coarse matter, so they are separated before biological treatment with active sludge. For subsequent purification, various physico-chemical, chemical and biological treatment methods can be applied [9-13].

This paper presents the study of the water pollution degree from poultry and the swine slaughterhouses as well as the possibility of reducing the quantity of pollutants by the activated-sludge treatment method $[9,11]$.

\section{EXPERIMENTAL SETUP}

The wastewater was sampled from S.C. Agricola International S.A. Bacau (Romania) whose activities include the slaughter and processing of poultry which generates around $350 \mathrm{~m}^{3}$ of wastewater per hour and from S.C. Nicbac Prod S.R.L. Nicolae Balcescu, Bacau (Romania) whose activities include the slaughter of swine.

In the literature, it is advisable to analyze water samples as soon as possible after sampling, because the loss of some gaseous substances can result as changes of temperature and pressure. Microbial activity can also contribute to changing the ammonium nitrate-nitrate balance, or may decrease the content of organic compounds that degrade rapidly for more than 4 hours.

Slaughterhouse wastewater is usually evaluated in terms of bulk parameters due to the specific amounts of SWW and pollutant loads related to the animals slaughtered and processed that vary among the meat processing industry, usually containing considerable amounts of total phosphorus (TP), total nitrogen (TN), chemical oxygen demand (COD), total suspended solids (TSS), and biochemical oxygen demand ( $\left.\mathrm{BOD}_{5}\right)$ [14].

The samples were collected into $1 \mathrm{~L}$ polyethylene bottles and were processed immediately or they were stored at $4{ }^{\circ} \mathrm{C}$ until analysis. Within the first 4 hours, we performed the following determinations: temperature, $\mathrm{pH}$, dissolved oxygen (DO), turbidity, biochemical oxygen demand $\left(\mathrm{BOD}_{5}\right)$, chemical oxygen demand (COD), total suspended solids (TSS), fixed residue, $\mathrm{NO}_{2}^{-}, \mathrm{NO}_{3}^{-}, \mathrm{SO}_{4}{ }^{2-}, \mathrm{Cl}-\mathrm{Fe}$, and $\mathrm{Cu}$ contents. Biochemical oxygen demand $\left(\mathrm{BOD}_{5}\right)$ of wastewater from poultry and swine slaughterhouses was determined by the difference between the amount of oxygen presented in the sample initially and after five days of storage at standard conditions: temperature $20^{\circ} \mathrm{C}$ and without of air and light.

The chemical oxygen demand (COD) test applied consisted in the ability of potassium permanganate to oxidize organic substances from water in acid condition, and excess permanganate is determined with oxalic acid. Another indicator is the sediment, which shows the amount of sedimentable suspensions for 2 hours due to gravitational force. To determine the sediment an Imhoff cone with $1000 \mathrm{~mL}$ capacity was used.

Total suspended solids (TSS) represent another important parameter used in defining the wastewater quality, which refers to all small particles suspended in water. Separation of the suspended matter by filtration was followed by bringing the residue to constant weight. Before analysis, the sample was vigorously shaken. Filtration was performed through filter paper for samples with a high content of suspended solids, and for samples with small content, through the crucible type G4 with asbestos layer. Centrifugation (Universal $320 \mathrm{R}$ ) was performed for samples that contain large amounts of colloidal materials.

Fixed residue indicates all the organic and inorganic substances dissolved in water and not volatile at $105^{\circ} \mathrm{C}$.

The principle of the method consists in separating of the hydrosoluble substances by evaporating of the water followed by weighing of the resulting residue. A measured volume of unfiltered water was evaporated on a water bath (Brookefield TC 502). The residue was dried at $105{ }^{\circ} \mathrm{C}$ in a MEMMERT vacuum drying oven and was weighed. By comparison, the fixed residues on the two types of SWW were also analyzed. For this, the separation of organic and inorganic substances dissolved in water by evaporation at $105{ }^{\circ} \mathrm{C}$, followed by their weighing has been performed.

Dissolved oxygen DO is important for the sanitary characterization of water; the higher is it, the higher is the level of water pollution and the danger to the consumers' health.

The method consists in calculating the difference between the amount of oxygen under saturation conditions and the amount of oxygen found in the water. Knowing the amount of oxygen dissolved in water and the amount of oxygen under saturation conditions using Winckler table was determined the oxygen deficiency (in \%). 
The content of suspensions, nitrates, nitrates, sulphates, phosphates, free chlorine, total chlorine, total iron, copper were accomplished using Hach DR / 2010 portable spectrophotometer. To achieve the above assays (exception of suspensions, phosphates and iron) 1:10 dilutions were required. For the determination of dissolved oxygen, temperature and $\mathrm{pH}$, we used the oxygen sensor model DurOx 325 . The turbidity of the waste water was conducted using the 2100P Portable Turbidimeter.

The active sludge treatment was chosen as method of reducing the pollutants content present in the wastewater. The purification principle consists in the development of bacterial flora originating from waste water and activated sludge, which in the presence of oxygen consumes organic pollutants. The active sludge is a complex colloidal system with a heterogeneous composition containing colloidal particles $(\mathrm{d}<1 \mu)$, dispersed particles $(\mathrm{d}$ $=1-100 \mu \mathrm{m})$, aggregates, suspension material, etc., having a gelatinous appearance and with high water content. From microbiological point of view, the active sludge is a mixture of microorganisms that consume the biodegradable material contained in the wastewater. The active sludge used in the experimental part comes from the secondary decanter of the city purification station of Bacau Municipality. In order to highlight the reduction of pollution, the analyses were carried out on the waste water and the samples from the biological treatment process.

Laboratory biological treatment was carried out in a $2 \mathrm{~L}$ capacity vessel in which waste water was introduced and inoculated with active sludge at a rate of $1 \mathrm{~g} \cdot \mathrm{L}^{-1}$. The sample was kept under magnetic agitation and aeration for 24 hours at $20^{\circ} \mathrm{C}$ at atmospheric pressure. After purification, the same determinations as in the initial sample were made.

\section{RESULTS AND DISCUSSION}

As a result of the continuous stirring and aeration of the mixture of wastewater and active sludge for 24 hours, brown mud flasks are deposited on the bottom of the container after magnetic stirring ceases. The results obtained from the analyses are presented in Tables 1 and 2 . The values of the physicochemical parameters and heavy metals determined in this study were compared with the maximum admissible values provided by the Romanian (NTPA 002/2005).

Table 1. Quality indicators for wastewater from pig's slaughterhouse.

\begin{tabular}{|c|c|c|c|c|c|}
\hline Quality indicator & Unit & $\begin{array}{l}\text { Waste } \\
\text { water }\end{array}$ & $\begin{array}{c}\text { Treated } \\
\text { water }\end{array}$ & $\begin{array}{c}\text { Efficiency } \\
{[\%]}\end{array}$ & $\begin{array}{l}\text { Maximum admissible } \\
\text { values according to } \\
\text { NTPA } 002 / 2005 \\
\end{array}$ \\
\hline $\mathrm{BOD}_{5}$ & $\mathrm{mg} \cdot \mathrm{L}^{-1}$ & 575.6 & 350.5 & 40 & 300 \\
\hline \multirow{2}{*}{ COD-Mn } & $\mathrm{mg} \mathrm{KMnO}_{4} \cdot \mathrm{L}^{-1}$ & 465.5 & 399.2 & 15 & - \\
\hline & $\mathrm{mg} \mathrm{O}_{2} \cdot \mathrm{L}^{-1}$ & 116.375 & 99.8 & 15 & 125 \\
\hline Total Suspensions & $\mathrm{mg} \cdot \mathrm{L}^{-1}$ & 610.1 & 170.0 & 72 & 300 \\
\hline Sediment & $\mathrm{mL} \cdot \mathrm{L}^{-1}$ & 7.5 & 15.0 & - & - \\
\hline Fixed residue & $\mathrm{mg} \cdot \mathrm{L}^{-1}$ & 2100 & 1300 & 38 & 1200 \\
\hline $\mathrm{O}_{2}$ dissolved & $\mathrm{mg} \mathrm{O} \cdot \mathrm{L}^{-1}$ & 1.7 & 2.2 & - & 6 \\
\hline Temperature & ${ }^{\circ} \mathrm{C}$ & 10 & 21.9 & - & 40 \\
\hline $\mathrm{pH}$ & - & 5.7 & 6.0 & - & $6.5-8.5$ \\
\hline Nitrates $(500 \mathrm{~nm})$ & $\mathrm{mg} \cdot \mathrm{L}^{-1}$ & 13.5 & 2.0 & 85 & 2 \\
\hline Nitrites $(585 \mathrm{~nm})$ & $\mathrm{mg} \cdot \mathrm{L}^{-1}$ & 86.0 & 60.0 & 30 & \\
\hline Sulphates $(450 \mathrm{~nm})$ & $\mathrm{mg} \cdot \mathrm{L}^{-1}$ & 63.0 & 55.0 & 13 & 600 \\
\hline Phosphates $(890 \mathrm{~nm})$ & $\mathrm{mg} \cdot \mathrm{L}^{-1}$ & 5.9 & 2.0 & 66 & \\
\hline Free chlorine $(530 \mathrm{~nm})$ & $\mathrm{mg} \cdot \mathrm{L}^{-1}$ & 0.4 & 0.01 & 90 & 0.5 \\
\hline Total chlorine $(530 \mathrm{~nm})$ & $\mathrm{mg} \cdot \mathrm{L}^{-1}$ & 0.6 & 0.2 & 67 & \\
\hline $\mathrm{Fe}(510 \mathrm{~nm})$ & $\mathrm{mg} \cdot \mathrm{L}^{-1}$ & 0.31 & 0.07 & 77 & \\
\hline $\mathrm{Cu}(560 \mathrm{~nm})$ & $\mathrm{mg} \cdot \mathrm{L}^{-1}$ & 0.37 & 0.09 & 75 & 0.2 \\
\hline Turbidity & NTU & 51.9 & 42.1 & 30 & - \\
\hline Deficit $\mathrm{O}_{2}$ & $\%$ & 26.0 & 20.0 & 6 & - \\
\hline
\end{tabular}


Table 2. Quality indicators for wastewater from poultry's slaughterhouse.

\begin{tabular}{|l|c|c|c|c|c|}
\hline \multicolumn{1}{|c|}{$\begin{array}{c}\text { Quality } \\
\text { indicator }\end{array}$} & Unit & $\begin{array}{c}\text { Waste } \\
\text { water }\end{array}$ & $\begin{array}{c}\text { Treated } \\
\text { water }\end{array}$ & $\begin{array}{c}\text { Efficiency } \\
{[\%]}\end{array}$ & $\begin{array}{c}\text { Maximum admissible } \\
\text { values according to } \\
\text { NTPA 002/2005 }\end{array}$ \\
\hline $\mathrm{BOD}_{5}$ & $\mathrm{mg} \cdot \mathrm{L}^{-1}$ & 833.9 & 700.0 & 16 & 300 \\
\hline COD-Mn & $\mathrm{mg} \mathrm{KMnO} \cdot \mathrm{L}^{-1}$ & 498.4 & 423.4 & 15 & - \\
\cline { 2 - 6 } & $\mathrm{mg} \mathrm{O} \cdot \mathrm{L}^{-1}$ & 124.6 & 105.85 & 15 & 125 \\
\hline $\begin{array}{l}\text { Total } \\
\text { Suspensions }\end{array}$ & $\mathrm{mg} \cdot \mathrm{L}^{-1}$ & 600.0 & 150.0 & 75 & 300 \\
\hline Sediment & $\mathrm{mL} \cdot \mathrm{L}^{-1}$ & 8.0 & 12.0 & - & - \\
\hline Fixed residue & $\mathrm{mg} \cdot \mathrm{L}^{-1}$ & 2800 & 1400 & 50 & 1200 \\
\hline $\mathrm{O}_{2}$ dissolved & $\mathrm{mg} \mathrm{O} \cdot \mathrm{L}^{-1}$ & 1.90 & 2.58 & - & 6 \\
\hline Temperature & ${ }^{\circ} \mathrm{C}$ & 10 & 20 & - & 60 \\
\hline pH & - & 7.1 & 7.6 & - & 2 \\
\hline $\begin{array}{l}\text { Nitrates }(500 \\
\text { nm) }\end{array}$ & $\mathrm{mg} \cdot \mathrm{L}^{-1}$ & 58 & 40 & 18 & - \\
\hline Turbidity & $\mathrm{NTU}$ & 50.8 & 48.0 & 3 & - \\
\hline Deficit $\mathrm{O}_{2}$ & $\%$ & 25.1 & 22.3 & 4 & 2,5 \\
\hline
\end{tabular}

It has been found that the sediment volume in the waste water deposited for 30 minutes varies as shown in the graphs from Figures 1 and 2.

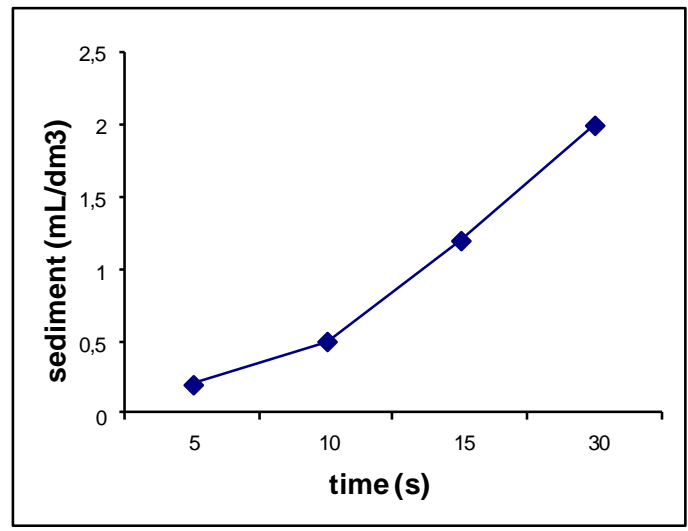

Fig.1.Variation of sediment volume deposited in time on water from poultry' slaughterhouse.

According to the values of qualitative indicators mentioned in Tables 1 and 2, there is a perceptible decrease of the pollutant content, which indicates that the process is viable. The results of the $\mathrm{BOD}_{5}$ and COD-Mn analyses showed that the pollution degree is higher in the case of wastewater from the poultry abattoir than the wastewater from the slaughterhouse.

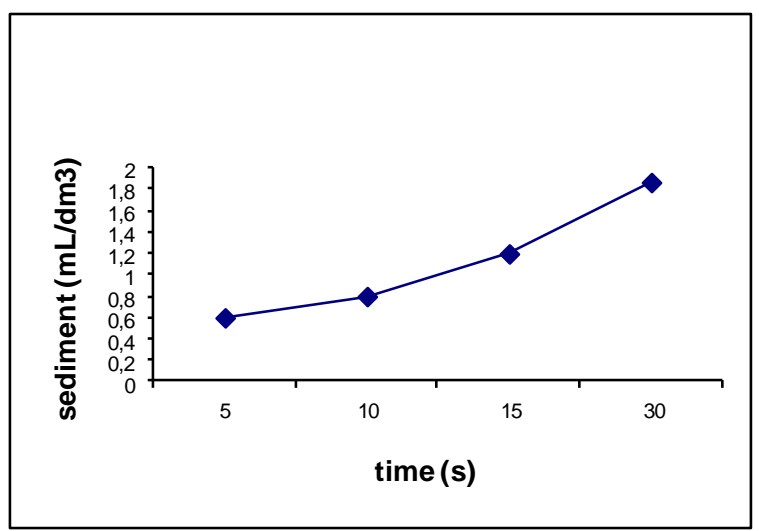

Fig.2. Variation of sediment volume deposited in time on water from pigs' slaughterhouse. 
The amount of turbidity in the poultry slaughter water indicates higher blood content than solid suspensions. For porcine abattoir wastewater, a $30 \%$ turbidity decrease is observed indicating a decrease in hemoglobin content and suspensions.

The degree of purification efficiency calculated for the two types of wastewater in terms of total suspension and fixed residue content is $50 \%$ for poultry slaughter water and $40 \%$ for swine sewage water. The water purification rate of the swine slaughterhouse calculated on $\mathrm{BOD}_{5}$ is $40 \%$.

For the $\mathrm{pH}$ of the wastewater from the pig slaughterhouse there is an increase from 7.12 to 7.6, and in the case of the swine sewage water there is an increase from 5.7 to 6 .

\section{CONCLUSIONS}

The biological treatment of the slaughterhouse wastewater with activated-sludge process presents some important advantages:

- cleaning process leading to an impregnable effluent;

- reduced smells emitted in technology;

- high efficiency for $\mathrm{BOD}_{5}$ and for decanter suspensions;

- low investment cost.

\section{REFERENCES}

[1] De Sena, R.F., Moreira, R.F.P.M., Jose, H.J., Comparison of coagulants and coagulation aids for treatment of meat processing wastewater by column flotation, Bioresource Technology, vol. 99, no. 17, 2008, p. 8221-8225.

[2] Bustillo-Lecompte, C.F., Mehrvar, M., Slaughterhouse wastewater characteristics, treatment, and management in the meat processing industry: A review on trends and advances, Journal of Environmental Management, vol. 161, 2015, p. 287-302.

[3] Johns, M.R., Developments in wastewater treatment in the meat processing industry: A review, Bioresource Technology, vol. 54, no. 3, 1995, p. 203-216.

[4] Suceveanu, I., Prevenirea poluării mediului prin minimizarea subproduselor rezultate de la procesarea industrială a cărnii şi valorificarea superioară a acestora, Teză de doctorat, Universitatea Tehnică "Gh. Asachi" Iaşi, 2009.

[5] Suceveanu, I., Suceveanu, M., Ciobanu, D., Pig slaughtering technology by scalding-skinning. technological modifications with implications in mitigation of the environmental pollution, Scientific Study \& Research Chemistry \& Chemical Engineering, Biotechnology, Food Industry, vol. IX, no. 4, 2008, p. 489-496.

[6] Suceveanu, I., Alexa, I.-C., Grosu, L., Patriciu, O.-I., Ifrim, I., Suceveanu, M.: Application of the HACCP method in the swine abattoir by scalding-skinning ecological processing, Scientific Study \& Research Chemistry \& Chemical Engineering, Biotechnology, Food Industry, vol. 18, no. 1, 2017, p. 73-84.

[7] Mittal, G.S., Treatment of wastewater from abattoirs before land application - a review, Bioresource Technology, vol. 97, no. 9, 2006, p. 1119-1135.

[8] De Sena, R.F., Tambosi, J.L., Genena, A.K., Moreira, R.F.P.M., Schröder, H.F., José, H.J., Treatment of meat industry wastewater using dissolved air flotation and advanced oxidation processes monitored by GC-MS and LC-MS, Chemical Engineering Journal, vol. 152, 2009, p. 151-157.

[9] Sayed, S., van Ampen, L., Lettinga, L., Anaerobic treatment of slaughterhousewaste using a granular sludge UASB reactor, Biological Wastes, vol. 21, 1987, p. 11-28.

[10] Barsan, N., Turcu, M., Nedeff, V., Mosnegutu, E., Chitimus, D., Laboratory Applications in Wastewater Treatment by Using Flocculation Process, Journal of Engineering Studies and Research, vol. 23, no. 3, 2017, p. 7-11.

[11] Bohdziewicz, J., Sroka, E., Lobos, E., Application of the system which combines coagulation, activated sludge and reverse osmosis to the treatment of the wastewater produced by the meat industry, Desalination, vol. 144, 2002, p. 393-398.

[12] Tritt, W.P., Schuchardt, F., Materials flow and possibilities of treating liquid and solid wastes from slaughterhouses in Germany. A review, Bioresource Technology, vol. 41, no. 3, 1992, p. 235-245.

[13] Cao, W., Mehrvar, M., Slaughterhouse wastewater treatment by combined anaerobic baffled reactor and UV/ $\mathrm{H}_{2} \mathrm{O}_{2}$ processes, Chemical Engineering Research and Design, vol. 89, 2011, p. 1136-114.

[14] NTPA 002/2005, Normativ privind condițiile de evacuare a apelor uzate în rețelele de canalizare ale localităților și direct în stațiile de epurare. 